\title{
FABRY NEFROPATIJA
}

\author{
Marius Miglinas $^{1}$, Pranas Šerpytis ${ }^{2}$, Urtė Gargalskaitė ${ }^{3}$, Justė Danieliūté $\dot{e}^{3}$, Algirdas Utkus ${ }^{4}$ \\ ${ }^{1}$ Vilniaus universitetinès ligoninès Santariškiu kliniku Nefrologijos centras, ${ }^{2}$ Vilniaus universitetinès \\ ligoninès Santariškiu kliniku Kardiologijos ir angiologijos centras, ${ }^{3}$ Vilniaus universiteto Medicinos \\ fakultetas, ${ }^{4}$ Vilniaus universiteto Medicinos fakulteto Žmogaus ir medicininès genetikos katedra
}

Raktažodžiai: Anderson - Fabry liga, Fabry nefropatija, pakaitinè fermento terapija, hemodializè, inkstų transplantacija.

\section{Santrauka}

Anderson-Fabry liga - tai igimtas glikosfingolipidu apykaitos sutrikimas, paveldimas su X chromosoma susijusiu recesyviniu būdu. GLA geno mutacija lemia fermento alfa-galaktozidazès A trūkumą ir nesuskaldytų glikosfingolipidų kaupimąsi viso organizmo ląsteliu lizosomose. Liga pasireiškia skausmo priepuoliais, galūnių parestezijomis, angiokeratomomis odoje ir gleivinėse, hipohidroze, inkstų, širdies ir centrinès nervų sistemos (CNS) pažeidimais. Pastarosios trys šio sutrikimo komplikacijos yra pagrindinès mirties priežastys sergant Anderson -Fabry liga. Vaikysteje Fabry nefropatija gali nepasireikšti jokiais klinikiniais simptomais, tačiau vyresniame amžiuje atsiradus reikšmingai proteinurijai, liga progresuoja labai greitai iki galutinès inkstų ligos. Proteinurija, hipertenzija, padidejęs serumo kreatinino kiekis ir sumažejęs glomerulų filtracijos greitis yra pagrindiniai progresuojančios inkstų ligos požymiai. Daugelio AFL pacientų, sergančių galutine inkstų ligos stadija, kraujospūdis yra didesnis už rekomenduojamą, todèl dèl reikšmingos koreliacijos su proteinurijos dydžiu turètų būti taikoma adekvati jo kontrolè. Gydant Fabry nefropatija sergančius pacientus pirmiausia daugiausia dèmesio skiriama kraujospūdžio, lipidų ir proteinurijos kontrolei, o pagrindinis gydymo metodas pacientams, kuriems pasireiškia galutinès stadijos inkstų liga, yra inkstų transplantacija. Dažnai dèl kitų klinikinių AFL manifestacijų trūkumo, daugeliui pacientų, kuriems nustatomas inkstų pažeidimas, pradinè diagnozė formuluojama kaip lètinis glomerulonefritas. Tokia preliminari diagnozė buvo nustatyta ir šiame straipsnyje nagrinejjamo klinikinio atvejo metu. Atliktas histologinis inksto bioptato tyrimas ir molekulinis genetinis ištyrimas leido patvirtinti Anderson-Fabry ligą.

\section{Ivadas}

Anderson-Fabry liga (AFL) - tai igimtas su X chromosoma susijęs glikosfingolipidų apykaitos sutrikimas, sukeltas fermento alfa-galaktozidazès A trūkumo dèl $G L A$ geno, koduojančio šị fermentą, mutacijos, lemiančios nesuskaldytų glikosfingolipidų kaupimąsi kraujagyslių endotelio, kardiomiocitų, laidžiosios sistemos ląstelių, vožtuvų fibrocitų, lygiujų raumenų ląstelių, inkstų ir nervų ląstelių lizosomose [1]. Kliniškai liga pasireiškia odos pažeidimais (angiokeratomos), pilvo skausmo priepuoliais ir diarèja, ragenos drumstumu, hipohidroze, periferinemis neuropatijomis [2]. Hemizigotams vyrams odos angiokeratomos, akroparestezijos ir sumažejęs prakaitavimas yra tipiniai ankstyvieji AFL simptomai, prasidedantys dažniausiai vaikysteje. Gyvybei pavojingos komplikacijos yra Fabry kardiomiopatija, cerebrovaskulinès ligos ir inkstų pažeidimas [3]. Dažnai liga pradideda vaikystejje ir vèliau pasireiškia kardiovaskulinès sistemos sutrikimais ar terminalinès stadijos inkstų liga [4]. Nuo 1898 m., kai ši liga buvo aprašyta pirmą kartą, apie ją sukaupta nemažai duomenų, atrastas saugus ir veiksmingas gydymo metodas - pakaitinè fermento terapija (PFT) [5]. Šiame straipsnyje pateikiame neseniai diagnozuotą ligos atveji Lietuvoje.

Darbo tikslas yra pateikti naujausius duomenis apie Anderson - Fabry ligos sukeltą nefropatiją, išanalizuoti ligos patogenezès ypatumus, pagrindinius simptomus, diagnostikos ir gydymo galimybes, šią informaciją iliustruojant Vilniaus universitetinès ligoninès Santariškių klinikose nustatytu ligos atveju.

\section{Klinikinis atvejis}

Moteriškos lyties 43 metų ligonė atvyko ị Vilniaus uni- 
versiteto ligoninès Santariškių klinikų (VUL SK) nefrologijos skyriu (2013-07-12). Atvykusi skundèsi skausmais nugaros srityje, galvos skausmais, ranku tirpimu. Taip pat kojų, rankų ir veido tinimu bei širdies plakimais. Pacientė pastebejo, kad kartais pakyla arterinis kraujo spaudimas. Tikrinantis ambulatoriškai aptinkamas baltymas šlapime.

Anamnezè. Pacientès žodžiais, pielonefritai pradejjo kartotis po pirmojo gimdymo (tuo metu ligonei buvo 17 metų ir nèštumo metu buvo labai ištinusi), kartodavosi vieną - du kartus per metus. Nuo trisdešimties metų amžiaus pielonefritai pradèjo kartotis dažniau, o prieš ketverius metus šlapime rasta baltymo.

$2011 \mathrm{~m}$. balandžio mèn atsiųsta gydytojo nefrologo konsultacijai į VUL SK. Atlikta inkstų echoskopija, patologijos nerasta. Nustatyta proteinurija (bendras baltymas šlapime $0,668 \mathrm{~g} / \mathrm{l}$; bendras baltymas paros šlapime 1,088 g/24 val.). Antikūnai prieš branduolio antigenus (ANA) neigiami; antikūnai prieš neutrofilų citoplazmą (ANCA) - neigiami. Nustačius neaiškios etiologijos proteinuriją pacientẻ hospitalizuota ị VULSK Nefrologijos centrą 201105-24 - 26 inksto biopsijai.

Preliminari diagnozè: lètinis glomerulonefritas; antrinè ŽSGS.

Atlikus histologini inksto bioptato ištyrimą, suformuluota patologijos diagnozé: minimalūs ir nespecifiniai pokyčiai inksto bioptate, su saikinga glomerulų hipertrofija ir podocitų vakuolizacija, be imunoreaktantų depozicijos. Papildomas atsakymas, atlikus elektroninès mikroskopijos tyrimą: patologinès sankaupos podocitų lizosomose (Zebra kūneliai), būdingos Fabry ligai arba jos nešiojimui (1 pav.).

Genealogija: pacientès motina sirgo inkstų liga, buvo dializuojama ir mirè 60 metų amžiaus; pacientès senelè iš motinos pusès taip pat sirgo inkstų liga ir mirè 67 metų amžiaus ( 2 pav.)

Fenotipas (2011-07-05): ūgis $167 \mathrm{~cm}$, svoris $93 \mathrm{~kg}$, KMI 33,35 (I laipsnio nutukimas), galvos apimtis $56 \mathrm{~cm}$, krūtinès ląstos apimtis $106 \mathrm{~cm}$. Hipersteninio kūno sudèjimo. Krūtinès vidurinèje linijoje rausva angiokeratoma. Pastoziškos blauzdos. Vidaus organuose auskultacijos, perkusijos ir palpacijos metodais patologijos nèra.

\section{Tyrimai}

- $\quad$ Lizosomų fermentų aktyvumo tyrimai (2011 07 08): nustatytas sumažèjęs alfa-galaktozidazès A aktyvumas iš sauso kraujo lašo mėginio - 175,96 pmol/spot 20 val. (norma 450-2000). Kitų tirtų fermentų aktyvumas normalus.

- Molekuliniai genetiniai tyrimai (2011 07 24): atliktas GLA geno tyrimas ir nustatyta mutacija 6 egzone c. $811 \mathrm{G}>\mathrm{T}$ G271C - heterozigotinè būklè.

- Instrumentiniai tyrimai: širdies magnetinio rezo- nanso tomografija (2012 11 08) - širdies ertmès nepadidèję; kairiojo skilvelio išstūmimo frakcija $66 \%$ (norma $>50 \%$ ); KS sienelès nesustorèjusios, pagausèjusi trabekuliarizacija; miokarde židininių pakitimų neišryškèjo.

Vidaus organų ultragarsiniai tyrimai: urogenitalinès sistemos sonoskopija (2011 05 04): pakitimų nerasta; virškinimo sistemos sonoskopija (2012 10 05): nustatyta hepatomegalija, hepatosteatozé; inkstų sonoskopija (2012 10 05): pakitimų nerasta.

Specialistų konsultacijos. Neurologo konsultacija: 2012-10-05 konsultuota gydytojo neurologo VUL SK Neurologijos centre. Pacientei atlikta elektroneurografija - polineuropatija ir riešo kanalo sindromas nenustatytas; ekstrakranijinių kraujagyslių dvigubas skenavimas - reikšmingų pokyčių nebuvo rasta. Gydytojas neurologas diagnozavo somatoforminę autonominę disfunkciją su cefalginiu, vestibuliniu sindromu ir méšlungiu rankose.

Oftalmologo konsultacija: 2012-11-08 konsultuota VUL SK gydytojo oftalmologo. Diagnozuoti specifiniai pokyčiai, būdingi Fabry ligai - corneae verticillatae ou.

Galutinė diagnozè: remiantis klinikiniais požymiais bei objektyvių tyrimų (fermentinis - sumažèjęs fermento alfa galaktozidazès aktyvumas, ir molekulinis genetinis - GLA geno mutacija) rezultatais diagnozuojama Anderson -Fabry liga.

Gydymas: siekiant sulètinti ligos progresavimą tikslinga pakaitiné fermento terapija agalsidase beta preparatu $1 \mathrm{mg} / \mathrm{kg}$ kūno svorio infuzija vieną kartą kas dvi savaites.

\section{Literatūros apžvalga}

Istoriniai faktai. Pirmą kartą ligą nepriklausomai vienas nuo kito 1898 m. aprašè du dermatologai: anglas Dr. William Anderson ir vokietis Dr. Johannes Fabry. Jie paskelbè straipsnius, kuriuose apibūdino pacientus su odos pažeidimais, žinomais kaip angiokeratomos, kurios dabar laiko-

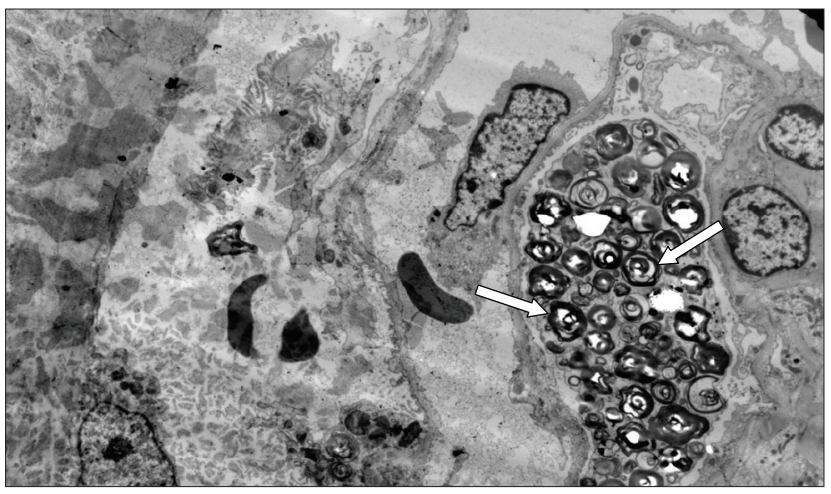

1 pav. Inkstų bioptato elektroninės mikroskopijos tyrimas. Rodyklëmis pažymėti Zebra kūneliai 
mos pagrindiniu Anderson - Fabry ligos simptomu. Liga turi keletą pavadinimų: angiokeratoma corporis diffusum, alfa-galaktozidazės A trūkumo liga, Anderson - Fabry liga. Šiuo metu pastarasis pavadinimas yra populiariausias, dažniausiai jis sutrumpinamas ir liga vadinama tiesiog Fabry liga.

Epidemiologija. Fabry liga pasaulyje pradèta registruoti nuo 2001 metų balandžio mènesio. Iki 2012 metų 304 gydytojai iš įvairių pasaulio šalių užregistravo 4167 pacientus, sergančius Fabry liga [6]. AFL pasireiškia nuo 1 iš 40000 iki 1 iš 117000 gimusių gyvų vyriškos lyties naujagimių. Naujausiose publikacijose teigiama, kad dèl dažno atipinių ligos formų, tokių kaip inkstų, širdies ar neurologinès, pasireiškimo vis dažniau stebima Fabry ligos hipodiagnostika. Šių formų (inkstų, širdies ir neurologinès) pasitaikymo dažnis yra 1 iš 3100 (klasikinis AFL variantas su vèlyvu Fabry ligos simptomų atsiradimu lyginant su atipiniu AFL variantu pasireiškia santykiu 11:1) [7]. Lètinè inkstų liga yra viena iš pagrindinių Fabry ligos išraiškų, kuri, remiantis Europos ir Amerikos dializių registru, sudaro 0,01 proc. visų galutinès inkstų ligos stadijos atvejų. Tačiau atrankiniai fermentu patikros tyrimai dializuojamiems vyriškos lyties pacientams rodo, kad tikrasis paplitimas gali būti nuo 10 iki 100 kartų didesnis, nes dauguma vyrų dèl galutinès inkstų ligos miršta 5-ame dešimtmetyje nesulaukę dializès ar inkstų transplantacijos [3]. Fabry ligos hipodiagnostika yra susijusi su nespecifiniais multiorganinio pažeidimo simptomais, taip pat daugeliui heterozigočiu moteru liga lieka nenustatyta dèl lengvesnio klinikinio pasireiškimo [8]. Tiek AFL sergančiujų vyrų, tiek moterų skaičius yra labai panašus: 2019 vyrų ir 2148 moterys. Daugiausia pacientų registruota Europoje ir Šiaurès Amerikoje. Vidutinis Fabry liga sergančių vyrų amžius yra 41 metai, moterų 45 metai. Pirmą kartą liga diagnozuojama vidutiniškai 25 metų vyrams ir 33 metų moterims [6].

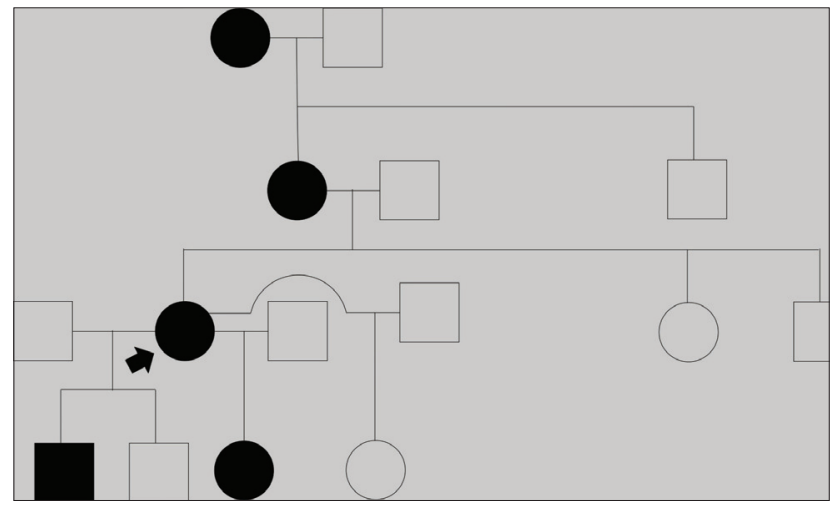

2 pav. Genealogija. Rodykle pažymèta straipsnyje nagrinèjama pacientè
Etiopatogenezè. Anderson-Fabry liga yra igimtas su X chromosoma susijęs paveldimas susirgimas, pasireiškiantis lizosominio fermento $\alpha$-galaktozidazès A trūkumu [9]. AFL lemia lizosomini fermentą $\alpha$ - galaktozidazę koduojančio geno defektas (GLA geno mutacija). GLA genas lokalizuojasi X chromosomos ilgajame petyje Xq22.1 srityje $[9,10]$. Jis atsakingas už fermento $\alpha$-galaktozidazès A gamybą, kurio aktyvumas pasireiškia ląstelių lizosomose, atsakingose už ląstelèse susidariusių metabolitų perdirbimą ir medžiagų apykaitos produktų pašalinimą iš ląstelès. Ivykus geno mutacijoms alfa-galaktozidaze A visiškai arba iš dalies nesusintezuojama, glikosfingolipidų (ypač Gb3) degradacijos kelias blokuojamas ir jie ima kauptis viso organizmo audiniuose, pirmiausia sukeldami kraujagyslių endotelio ląstelių proliferaciją, pažeisdami nervų sistemos, inkstų, odos ir raumenų (iskaitant ir širdies raumens) ląsteles [11,12]. Kaip ir kitais tipiniais su X chromosoma susijusiais ligų paveldejjimo atvejais, Fabry liga dažniausiai sunkesnè homozigotams vyrams nei heterozigotems moterims.

Endotelio ląstelių disfunkcija lemia nefrologines Fabry ligos komplikacijas, tačiau patologiniai mechanizmai, dèl kurių sutrinka endotelio ląstelių funkcija, yra labai mažai išnagrinèti. M. Hee Lee et al. atliko tyrimą su Fabry liga sergančiomis ir sveikomis pelèmis, kurio metu siekè išsiaiškinti, ar augimo faktorius $\beta 1$ (transforming growth factor- $\beta 1$ (TFG- $\beta 1))$ ir kraujagysliu endotelio augimo faktorius (vascular endothelial growth factor (VEGF)) turi itakos Fabry nefropatijos patogenezei. Buvo nustatytas šiu faktorių ekspresijos Fabry pelių inkstuose padidejjimas ir padarytos išvados, kad TFG- $\beta 1$ ir VEGF faktorių hiperekspresija gali dalyvauti Fabry nefropatijos patogenezèje kaip ląstelių apoptozę indukuojantis mechanizmas, dẻl kurios vystosi glomerulosklerozė ir intersticinè fibrozė [13]. Taigi inkstų pažeidimas žymiai dažniau gali būti susijęs su intersticine ir glomerulų fibroze bei randejjimu nei su Gb3 kaupimųsi parietalinèse ir visceralinèse glomerulų epitelio ląstelèse. Gb3 kaupimasis podocituose nèra tiesiogiai susijęs nei su proteinurijos dydžu, nei su Fabry nefropatijos progresavimo greičiu ir ligos sunkumu [14].

Fabry nefropatijos klinika ir diagnostika. Lètinè inkstų liga AFL sergantiems pacientams yra viena iš klasikinių Fabry ligos išraiškų, kartu su kardiovaskuliniu pažeidimu lemiančių daugumą šių pacientų ankstyvų mirčių [15]. Pirmiausia, tipiniai AFL simptomai yra angiokeratomos ir neuropatinio galūnių skausmo epizodai, atsirandantys vaikysteje. Vèliau AFL pasireiškia kairiojo skilvelio hipertrofija, proteinurija, galutine inkstų liga ir insultu. Šios vèlyvosios ligos manifestacijos nèra specifinès ir taip pat būdingos cukriniam diabetui, hipertenzijai ir ateromatozei, todèl daugelis klinicistų nepagalvoja apie AFL [15]. 
Paprastai proteinurija, hipertenzija, padidejęs serumo kreatinino kiekis ir sumažejęs glomerulų filtracijos greitis yra pagrindiniai progresuojančios inkstų ligos požymiai, o proteinurijos ir serumo kreatinino matavimai yra svarbiausi monitoruojant inkstų funkciją. Tačiau šie testai yra mažai jautrūs norint nustatyti ankstyvą inkstų pažeidimą, o nenormalios reikšmès dažniausiai yra jau pažengusios inkstų ligos požymiai, kai atsiranda negrižtami inkstų struktūros pažeidimai [16]. Inkstų pažeidimas, sergant AFL, vaikystèje gali nepasireikšti jokiais klinikiniais simptomais, tačiau vyresniame amžiuje atsiradus reikšmingai proteinurijai, Fabry nefropatija progresuoja labai greitai iki galutinès inkstų ligos. PFT nèra labai veiksminga išsivysčius proteinurijai ar sumažejus glomerulų filtracijos greičiui. Todèl ankstyva Fabry nefropatijos diagnostika ir gydymas yra labai svarbūs norint išvengti inkstų pažeidimo. Nepaisant šio žinojimo, nèra atlikta pakankamai studijų, kurios parodytų, kada reikia pradèti PFT [16].

Albuminurija ir proteinurija yra pagrindiniai progresuojančios Fabry nefropatijos radiniai, galintys pasiekti nefrozini lygị. Tačiau proteinurijos nebuvimas neleidžia atmesti AFL galutine inkstų liga sergantiems pacientams. Albuminurija galètų būti jautresnis žymuo nustatant inkstų pažeidimą Fabry ligoniams, tačiau jo prognostinè verté, kaip galutinès inkstų ligos progresavimo rizikos ịvertinimo žymuo, turètų būti įrodoma tolimesnèse studijose [3]. Daugelio AFL pacientų, sergančių galutine inkstų liga, kraujospūdis yra didesnis už rekomenduojamą, todèl turètų būti taikoma adekvati jo kontrolè, nes nustatyta, kad sisteminis kraujo spaudimas koreliuoja su proteinurijos dydžiu tiek vyrams, tiek moterims [3]. Dažnai dèl kitų klinikinių AFL manifestacijų trūkumo, daugeliui pacientų, kuriems nustatomas inkstų pažeidimas, pradinè diagnozė formuluojama kaip lètinis glomerulonefritas [8].

Kiekvienam AFL sergančiam pacientui turètų būti atliekami šie tyrimai, norint ịvertinti inkstų pažeidimą: kraujo serumo elektrolitai, kreatininas; 24 val. šlapimo ar vienkartinio šlapimo tyrimas nustatant bendrą baltymą/kreatininą, albuminą/kreatininą, natrị, kreatininą ir (pagal galimybes) Gb3. Inkstu biopsija gali būti naudinga kaip pradinis pažeidimo ịvertinimas pacientams su atipiniu ligos pasireiškimu, taip pat pakartotinés biopsijos atliekamos tuomet, kai nepaisant adekvataus gydymo liga progresuoja [14].

Nefrologijoje patikrą dèl Fabry ligos rekomenduojama atlikti tuomet, kai pasireiškia nepaaiškinama lètinè inkstų liga jaunesniems nei 50 metų vyrams ir bet kokio amžiaus moterims. Vyrams tai gali būti atliekama nustatant alfa-galaktozidazès A aktyvumą kraujo plazmoje, leukocituose ar sausame kraujo laše. Šiuo metu tai yra auksinis standartas diagnozuojant AFL vyrams, fermento tyrimo jautrumas ir specifiškumas siekia beveik 100 proc., taip pat neigiama prognostinè vertè yra 100 proc. Moterims būtinas molekulinis genetinis ištyrimas, nes atlikus tik fermentinị tyrimą, dèl X chromosomos inaktyvacijos, AFL nediagnozuojama vienam trečdaliui sergančių moterų. Patikra dèl AFL rekomenduojama taip pat ir tiems pacientams, kurie turi neigiamą šeiminę AFL anamnezę, nes gali pasireikšti de novo mutacijos [15].

Gydymas. Specifinis gydymas. Dar visai neseniai AFL gydymą sudare tik paliatyvi simptominè terapija: neuropatinio skausmo malšinimas analgetikais, prieštraukuliniais (antikonvulsiniais) ir nesteroidiniais vaistais nuo uždegimo $[17,18]$. Požiūris ị AFL gydymą pasikeitè ị klinikinę praktiką 2001 metais įdiegus specifinę Fabry ligai - pakaitinę fermento terapiją (PFT) $[10,17]$. Šiuo metu žinomi du rekombinantiniai fermento $\alpha$-galaktozidazès A preparatai: agalzidazè- $\alpha$ (Replagal $\AA)$, gaunama iš modifikuotų žmogaus ląstelių linijos, ir algalzidazè- $\beta$ (Fabrazyme $\AA$ ), gaminama Kinijos žiurkènų kiaušidžių ląstelèse [10]. Preparatai skiriami intraveniškai per $40 \mathrm{~min}$. kas dvi savaites, skiriasi tik jų dozavimas: agalzidazè- $\alpha$ po $0,2 \mathrm{mg} / \mathrm{kg}$, algalzidazè- $\beta$ po $1 \mathrm{mg} / \mathrm{kg}$, pradedant nuo $0,25 \mathrm{mg} / \mathrm{min}$. [18] Daugelio klinikinių tyrimų ịrodyta, kad šie preparatai mažina ligos simptomus (skausmo priepuolius, parestezijas), stabdo inkstų nepakankamumo, klausos pažeidimo progresavimą, pagerina gyvenimo kokybę [5].

Gydant Fabry nefropatija sergančius pacientus pirmiausia daugiausia dèmesio skiriama kraujospūdžio, lipidų ir proteinurijos kontrolei. AKF inhibitoriai ir angiotenzino receptoriu blokatoriai yra labai svarbūs gydant bet kokios kilmès proteinurija pasireiškiančias inkstų ligas. Svarbiausias pagalbinès terapijos principas pacientams, kuriems skiriama PFT, yra inkstų funkcijos stabilizavimas bei proteinurijos ir albuminurijos sumažinimas iki minimumo [15]. Naujausios studijos atskleidžia, kad antiproteinurinè terapija kartu su angiotenziną konvertuojančio fermento inhibitoriais ir/arba angiotenzino receptorių blokatoriais gali sustabdyti glomerulų filtracijos greičio mažejimo progresavimą pacientams, gydomiems Fabrazyme PFT skiriant $1 \mathrm{mg} / \mathrm{kg}$ kas 2 savaites. Vis dèlto šių tyrimų išvados turètų būti ratifikuotos didesnèse prospektyvinèse studijose [3].

Inksto persodinimo galimybès. Inkstu transplantacija yra pagrindinis gydymo metodas pacientams, kuriems pasireiškia galutinès stadijos inkstų liga. Svarbu tai, kad transplantuotame inkste Gb3 kaupimas nepasireiškia, nes $\alpha$-galaktozidazès A aktyvumas jame yra normalus (donoras turètų būti ištirtas, ar nèra mutavusio GLA geno nešiotojas) [14]. Lietuvoje ištirti inkstų kadaverinio inksto donoro nèra galimybès, todèl inkstų persodinimas būtų atliktas, tikintis, kad inksto donoras nèra mutavusio GLA geno nešiotojas 
[5].Vis dèlto nepaisant gerų inkstų transplantacija gydomų Fabry nefropatija sergančių pacientų rezultatų, išlieka didelè kardiovaskulinių ir cerebrovaskulinių ịvykių tikimybè, o mirštamumo dažnis dèl Fabry ligos transplantuotų ligoniu yra didesnis nei bendras trasplantuotų pacientų mirštamumas $[15,19]$.

\section{Išvados}

1. Anderson-Fabry liga yra igimtas su $\mathrm{X}$ chromosoma susijęs, recesyviniu būdu paveldimas susirgimas, lemiamas GLA geno mutacijos ir pasireiškiantis lizosomų fermento $\alpha$-galaktozidazès A trūkumu.

2. Lètinè inkstų liga AFL sergantiems pacientams yra viena iš klasikinių Fabry ligos išraiškų, kartu su kardiovaskuliniu pažeidimu lemiančių daugumą šių pacientų ankstyvų mirčių.

3. Proteinurija, hipertenzija, padidejęs serumo kreatinino kiekis ir sumažèjęs glomerulų filtracijos greitis yra pagrindiniai progresuojančios inkstų ligos požymiai, o proteinurijos ir serumo kreatinino matavimai yra svarbiausi monitoruojant inkstų funkciją.

4. Diagnozė patvirtinama vyrams nustatant alfa-galaktozidazės A aktyvumą kraujo plazmoje, leukocituose ar sausame kraujo laše. Šiuo metu tai yra auksinis standartas diagnozuojant AFL vyrams. Moterims dèl X chromosomos inaktyvacijos fermentinis tyrimas gali būti normalus, todèl būtinas molekulinis genetinis ištyrimas.

5. Specifinis gydymas - pakaitiné fermento terapija (PFT), šie preparatai mažina ligos simptomus (skausmo priepuolius, parestezijas), stabdo inkstų nepakankamumo, klausos pažeidimo progresavimą, pagerina gyvenimo kokybę. Taip pat būtina kraujospūdžio, lipidų ir proteinurijos kontrolè.

6. Inkstų transplantacija yra pagrindinis gydymo metodas pacientams, kuriems pasireiškia galutinès stadijos inkstų liga.

\section{Literatūra}

1. Imbriaco M, Pisani A, Spinelli L, Cuocolo A, Messalli G, Capuano E. et al. Effects of enzyme - replacement therapy in patients with Anderson - Fabry disease: a prospective long term cardiac magnetic resonance imaging study. Heart 2009 Jul; 95 (13): 1103-1107.

2. Hilz M J, Brys M, Marthol H. et al. Enzyme replacement therapy improves function of $\mathrm{C}-, \mathrm{A} \delta$-, and $\mathrm{A} \beta$-nerve fibers in Fabry neuropathy. Neurology 2004; 62: 1066.

3. Ortiz A, Oliveira J P, Waldek S, Warnock D G, Cianciaruso B, Wanner Ch. Nephropathy in males and females with Fabry disease: cross-sectional description of patients before treatment with enzyme replacement therapy. Nephrology Dialysis Transplantation 2008; 23: 1600-1607.
4. Desnick R J, Brady R, Barranger J, Collins A J, Germain D P, Goldman M. et al. Fabry Disease, an Under-Recognized Multisystemic Disorder: Expert Recommendations for Diagnosis, Management, and Enzyme Replacement Therapy. Annals of Internal Medicine 2003; 138: 338-346.

5. Dobrovolskienė R., Utkus A., Tumienè B., Rainienè T., Czartoryska B. Fabry liga (klinikinis atvejis ir literatūros apžvalga). Medicina (Kaunas) 2007; 43 Suppl 1.

6. Charrow J, Politei J M, Wanner Ch, Warnock D G. Fabry Registry Annual Report 2012.

7. http://www.lysosomalstorageresearch.ca/Fabry_eClinic/ebookhome.html. The FabryCardiac eBook. Visited in 20131006.

8. Rozenfeld PA. Fabry Disease: Treatment and Diagnosis; Critical Review. IUBMB Life 2009 November; 61(11): 1043-1050.

9. http://ghr.nlm.nih.gov/gene/GLA. Genetics Home Reference. Visited in 20131006.

10. O'Mahony C, Elliott P. Anderson-Fabry Disease and the Heart. Progress in Cardiovascular Diseases 52 (2010); 326-335.

11. Krüger R, Bruns K, Grünhage S. et al. Determination of globotriaosylceramide in plasma and urine by mass spectrometry. Clinical Chemistry and Laboratory Medicine 2010; 48(2): 189-198.

12. De Valbuena Bueno CR. Fabry Disease: Pathogenesis and Histopathology. 2012.

13. Lee MH, Choi EN, Jeon YJ, Jung SC. Possible role of transforming growth factor- $\beta 1$ and vascular endothelial growth factor in Fabry disease nephropathy. International Journal of Molecular Medicine 2012; 30: 1275-1280.

14. Eng Ch M, Germain DP, Banikazemi M, Warnock DG, Wanner $\mathrm{Ch}$, Hopkin R J. et al. Fabry disease: Guidelines for the evaluation and management of multi-organ system involvement. Genetics in Medicine 2006; 8(9): 539-548.

15. Terryn W, Cochat P, Froissart R, Ortiz A, Pirson Y, Poppe B. et al. Fabry nephropathy: indications for screening and guidance for diagnosis and treatment by the European Renal Best Practice. Nephrology Dialysis Transplantation 2013; 28: 505-517.

16. Najafian B, Mauer M, Hopkin RJ, Svarstad E. Renal complications of Fabry disease in children. Pediatric Nephrology 2013; 28: 679-687.

17. Sheppard MN. The heart in Fabry's disease, Review Article. Cardiovascular Pathology 2011; 20: 8-14.

18. Alegra T, Vairo F, de Souza MV, Krug B C, Schwartz IVD. Enzyme replacement therapy for Fabry disease: A systematic review and meta-analysis. Genetics and Molecular Biology. 2012; 35, 4 (suppl): 947-954.

19. Ortiz A, Cianciaruso B, Cizmarik M, Germain DP, Mignani R, Oliveira JP. et al. End-stage renal disease in patients with Fabry disease: natural history data from the Fabry Registry. Nephrology Dialysis Transplantation 2010; 25: 769-775. 


\section{FABRY NEFROPATHY}

M. Miglinas, P. Šerpytis, U. Gargalskaitė,

\section{J. Danieliūtè, A. Utkus}

Key words: Anderson - Fabry disease, Fabry nephropathy, enzyme replacement therapy, hemodialysis, kidney transplantation.

Summary

Anderson-Fabry disease (AFD) is a X-linked lysosomal storage disorder caused by mutations of the GLA gene that encodes $\alpha$-galactosidase $\mathrm{A}$, what causes intracellular accumulation of globotriaosylceramide. The main manifestations of AFD are pain attacks, acroparasthesias, cutaneous angiokeratomas, hypohydrosis, kidney, heart and cerebrovascular disorders. Late life-threatening complications include cardiomyopathy, cerebrovascular disease and renal injury. Fabry nephropathy may not appear with clinical signs and symptoms in childhood, but in the older adulthood occurs with significant proteinuria which leads to terminal kidney disease.

Proteinuria, hypertension, high level of serum creatinine and low glomerular filtration rate are the main symptoms of progressive kidney disease. Adequate blood pressure control is recommended as proteinuria appears to be correlated with systemic blood pressure in both sexes. Fabry nephropathy treatment focus on control of hypertension, lipids and proteinuria and the main method of patients with terminal kidney disease treatment is kidney transplantation. When there are lack of the other classical manifestations for patients with renal disease, most of these cases are initially diagnosed as chronic glomerulonephritis. In this clinical case chronic glomerulonephropathy was also stated as preliminary diagnosis. AFD was verified by kidney biopsy and genetic testing.

Correspondence to: marius.miglinas@santa.lt

Gauta 2013-12-11 